\title{
Foliar nitrogen dynamics of an invasive legume compared to native non-legumes in fynbos riparian zones varying in water availability
}

\author{
Casparus J Crous ${ }^{1,4 *}$, Deanne C Drake ${ }^{2}$, Anna L Jacobsen ${ }^{3}$, R Brandon Pratt ${ }^{3}$, Shayne M Jacobs ${ }^{4}$ \\ and Karen J Esler ${ }^{4,5}$ \\ 'South African Environmental Observation Network, Arid Lands Node, P.O. Box 110040, Hadison Park 8306, Kimberley, South Africa \\ ${ }^{2}$ Wisconsin Department of Natural Resources, USGS Upper Midwest Environmental Science Center, 2630 Fanta Reed Rd, La Crosse, WI, 54603, USA \\ ${ }^{3}$ Department of Biology, California State University, Bakersfield, 9001 Stockdale Hwy, Bakersfield, CA, 93311, USA \\ ${ }^{4}$ Department of Conservation Ecology and Entomology, Stellenbosch University, Private Bag X1, Matieland, 7602, South Africa \\ ${ }^{5}$ Centre for Invasion Biology, Stellenbosch University, Private Bag X1, Matieland, 7602, South Africa
}

\begin{abstract}
The legume Acacia mearnsii invades South Africa's fynbos riparian zones and may alter the nitrogen (N) dynamics and supply in these areas that typically support few native $\mathrm{N}$ fixers. Nitrogen uptake by $A$. mearnsii may also be influenced by water availability, potentially affecting riparian-specific performance and impact estimations. We expected to find functional differences between the invasive legume and the two co-occurring but non-leguminous native species Brabejum stellatifolium and Metrosideros angustifolia. We also wanted to examine whether in-situ water availability affected N source or uptake in the invasive species. We found $A$. mearnsii was indeed functioning differently from non-N-fixing native species, and had considerably higher foliar \%N. Interestingly, ${ }^{15} \mathrm{~N}$ abundance and uptake were associated with site hydrology, meaning water availability should be scrutinised when assuming $\mathrm{N}$-fixing in A. mearnsii using $\delta^{15} \mathrm{~N}$. Nonetheless, higher water availability to A. mearnsii in fynbos riparian ecosystems did increase foliar $\mathrm{N}$ uptake. This has implications for prioritizing clearing of sites with increased nutrient deposition, such as dense stands in relatively moist riparian zones.
\end{abstract}

Keywords: $\delta^{15} \mathrm{~N}$, Acacia mearnsii, Black Wattle, South Africa, stable isotopes, water stress

\section{INTRODUCTION}

The invasion of non-native Acacia into South African landscapes threatens the future integrity of many ecosystems (Le Maitre et al., 2011), especially those of the hyper-diverse fynbos biome (Wilson et al., 2014). The extensive invasion of A. mearnsii into fynbos riparian ecosystems is of particular concern (Van Wilgen et al., 2012): A. mearnsii populations decrease watershed yield of fresh water (Enright, 2000; Dye and Jarmain, 2004; Van Wilgen et al., 2007), and this in a region already predicted to experience more drought events due to climate changes (New, 2002; Steynor et al., 2009). Among the main invasive tree species in South Africa today, A. mearnsii is considered the largest contributor to water flow reductions (Le Maitre et al., 2016).

In addition to worsening water stress for native plant communities, nitrogen (N)-fixing A. mearnsii will likely affect $\mathrm{N}$ cycling and thus local ecosystem functioning (Lee et al., 2017). Non-legumes rely mainly on soil-available ammonium and nitrate, whereas legumes are capable of fixing abundant atmospheric $\mathrm{N}$ via microbial symbioses, thereby adding $\mathrm{N}$ to the plant-soil system. Legumes are, therefore, expected to have higher levels of $\mathrm{N}$ accumulated in plant material compared to reference non-fixers (Wright et al., 2004). For example, in Australia, A. mearnsii had significantly higher foliar $\% \mathrm{~N}$ than a co-occurring but non-N-fixer, Eucalyptus globulus (Forrester et al., 2007). In nutrient-poor fynbos soils, a higher leaf $\% \mathrm{~N}$ may thus improve growth and persistence of $A$. mearnsii in the landscape (Sardans et al., 2017). Subsequently dense stands

To whom all correspondence should be addressed.

e-mail: casper@saeon.ac.za

Received 1 November 2017, accepted in revised form 12 December 2018 of N-enriched A. mearnsii would also increase terrestrial and aquatic nutrient pollution in catchments (Chamier et al., 2012; Tye and Drake, 2012).

Nitrogen dynamics in landscapes where legumes invade may vary depending on the relative access of the plant to water in that landscape (Dudley et al., 2014). This $\mathrm{N}$ variation might be reflected in site-specific plant performance and thus affect future environmental impact estimations. Since legumes could also acquire different $\mathrm{N}$ sources compared to co-occurring native plants (Högberg, 1997; Robinson, 2001), studying the natural abundances of ${ }^{15} \mathrm{~N}:{ }^{14} \mathrm{~N}$ in foliage could further explain variation in $\mathrm{N}$-source uptake between invasive $\mathrm{N}$-fixers and native non-N-fixing plants in the landscape (Nielsen et al., 2016). Interestingly, $\delta^{15} \mathrm{~N}$ appears negatively related to water availability when measured as mean annual precipitation, but positively related to landscape-scale measures such as moisture patches (Handley et al., 1994). Both foliar $\% \mathrm{~N}$ and $\delta^{15} \mathrm{~N}$ could therefore provide an integrated view of how legume invasion has the potential to impact nutrient dynamics in the landscape (Stock et al., 1995), and how these impacts might vary with local water availability (Handley et al., 1994).

Leaf $\mathrm{N}$ dynamics of invading $A$. mearnsii under conditions of varying water availability in fynbos riparian zones have not been examined. Higher leaf-N content may lead to greater rates of $\mathrm{CO}_{2}$ uptake, resulting in a sustained cycle of increased $\mathrm{N}$ assimilation in the roots and other organs (Field et al., 1983; Cernusak et al., 2009). By reanalysing published plant waterstress data $\left(\delta^{13} \mathrm{C}\right.$, predawn $\left[\Psi_{(\mathrm{pd})}\right]$ and midday $\left[\Psi_{(\mathrm{md})}\right]$ water potentials; Crous et al., 2012) and $\%$ foliar N, $\delta^{15} \mathrm{~N}, \mathrm{C}$, and $\mathrm{C}: \mathrm{N}$ ratios from the same samples, we aimed to study leaf $\mathrm{N}$ dynamics as functions of both species-specific functional traits and riparian-specific water availability (sensu Schulze et al., 1991). We thus assessed this question of functional variation in a multivariate fashion (Walker et al., 1999; Petchey and Gaston, 
2002), hypothesising first that the invasive legume would be functionally different from co-occurring native riparian species that are not leguminous (Lee et al., 2017), and second that in-situ water availability would positively correlate with foliar $\mathrm{N}$ and $\delta^{15} \mathrm{~N}$ values, potentially affecting $\mathrm{N}$ source and uptake by A. mearnsii in moister or drier riparian zones.

\section{METHODS}

\section{Foundation and extant data}

\section{Sites}

The evergreen non-native and invasive legume, Acacia mearnsii De Wild (Fabaceae), was compared to two native, evergreen, and non-leguminous fynbos riparian species, Brabejum stellatifolium (L.) (Proteaceae) and Metrosideros angustifolia (L.) (Myrtaceae). These native species were selected as they consistently co-occur with the invasive in the landscape, and are also considered key species in fynbos riparian zones (Galatowitsch and Richardson, 2005). There were no dominant native leguminous tree species for comparison with $A$. mearnsii. The three study sites were the Eerste River at Jonkershoek $\left(33^{\circ} 57.621^{\prime} \mathrm{S}, 18^{\circ} 55.037^{\prime} \mathrm{E} ; 200 \mathrm{~m}\right.$ a.s.l.), Wit River at Bainskloof $\left(33^{\circ} 34.217^{\prime} \mathrm{S}, 19^{\circ} 08.452^{\prime} \mathrm{E} ; 279 \mathrm{~m}\right.$ amsl) and Molenaars River at DuToitskloof $\left(33^{\circ} 41.778^{\prime} \mathrm{S}, 1^{\circ} 13.263^{\prime} \mathrm{E}\right.$; $297 \mathrm{~m}$ amsl). At each site 5 individuals per species were marked for leaf sampling and water-stress measurements $(n=5)$. However, one A. mearnsii individual was lost at Jonkershoek during the course of the study due to wood harvesting, rendering $n=4$ for this site. All sampled tree individuals were between 2 and $4 \mathrm{~m}$ in height, and were similar in leaf size.

\section{Foliar carbon and nitrogen stable isotope analysis}

Ten mature leaves from the well-exposed outer canopy of each tree were harvested from each individual, stored in paper bags and dried at $40^{\circ} \mathrm{C}$ until a constant weight was achieved. Dried leaves were crushed into a fine powder with a mortar and pestle and powdered leaf samples of approx. $2.852 \pm 0.025 \mathrm{mg}$ each were analysed for $\% \mathrm{~N}, \% \mathrm{C}, \delta^{15} \mathrm{~N}, \delta^{13} \mathrm{C}$ and C: $\mathrm{N}$ by combustion in an automated Flash EA 1112 elemental analyser (CarloErba), coupled with a Delta Plus XP isotope mass spectrometer. These analyses were carried out in the Stable Light Isotope Unit, in the Department of Archaeology at the University of Cape Town. Stable isotope data were expressed as:

$$
\delta(\mathrm{x})(\% \mathrm{o})=\left(\left(R_{\text {sample }}-R_{\text {standard }}\right) / R_{\text {standard }}\right) \times 1000
$$

where $R_{\text {sample }}$ is the ${ }^{13} \mathrm{C} /{ }^{12} \mathrm{C}$ or ${ }^{15} \mathrm{~N} /{ }^{14} \mathrm{~N}$ ratio of the sample.

\section{Leaf water potentials}

Water potential measurements were carried out on the same individuals. Three healthy shoots were cut from each individual and leaf water potential was measured immediately on site using a pressure chamber (PMS Instruments, Covallis, Oregon, USA). Predawn and midday water potential measurement were replicated on three non-consecutive days for each species across all sites, ultimately totalling 45 predawn and 45 midday measurements for each species at each site. Sampling took place in the summer season (Dec-Feb 2008/2009), when most plants would experience the most water-stressed conditions. Leaf water potential data were previously published in Crous et al. (2012).

\section{Explanatory variables}

The following categorical explanatory variables were included in the multivariate analysis to determine functional differences in foliar \% $, \% \mathrm{C}, \delta^{15} \mathrm{~N}, \delta^{13} \mathrm{C}$ and $\mathrm{C}: \mathrm{N}$ across the three species:

1. Site water availability: Sites were categorized by their relative water availability to plants. This was done using predawn water potential values $\left(\Psi_{(\mathrm{pd})}\right)$; which correspond to the maximum level of hydration and the soil moisture that the plants have access to), midday values $\left(\Psi_{(\mathrm{md})}\right)$; which provide the water potential at the maximum level of water deficit for the day), and site-specific geomorphological conditions (which may influence water availability at each site) as described in Crous et al. (2012). These data suggested Bainskloof to be the riparian zone where trees experienced the most water stress (lowest water potentials), even though this catchment does not have the lowest streamflow volume. Trees at the other two sites had similar, higher water potentials during prevailing summer conditions. Trees at Bainskloof $(n=15)$ were thus categorized as having lower site water availability with those at Jonkershoek and DuToitskloof having higher site water availability $(n=29)$.

2. Relative root access to groundwater: The relative root access to groundwater during the day $\left(\Psi_{(\text {delta) }}=\Psi_{(\mathrm{md})}-\Psi_{(\mathrm{pd})}\right)$ provides an indication of the range of water potentials a species operates at during transpiration. A lower $\Psi_{\text {(delta) }}$ could indicate a species restricting transpiration via stomatal closure, and a higher value could indicate a species transpiring to a greater degree, or that resistance to water transport is greater in the soil-plant hydraulic pathway.

3. Plant functional type: Plant functional type was categorized as being a legume or not, which indicates the potential for $\mathrm{N}$ fixation and greater $\mathrm{N}$-uptake capacity in nutrient-limited environments.

\section{Statistical analyses}

To test for significant differences in plant function between the invasive legume and the native nonlegumes, permutational multivariate analysis of variance (PERMANOVA; Anderson, 2001) was performed in PRIMER 6 (PRIMER-E 2008, Lutton, UK). Multivariate dissimilarity was calculated using Euclidean distances, and using 9999 permutations (Anderson 2001). Then, to test which of site water availability, relative root access to groundwater $\left[\Psi_{\text {(delta) }}\right]$, and plant functional type more strongly explained plant functional differences $\left(\% \mathrm{~N}, \% \mathrm{C}, \delta^{15} \mathrm{~N}, \delta^{13} \mathrm{C}\right.$ and $\mathrm{C}: \mathrm{N}$ ), and if these explanatory variables were positively or negatively related to traits, we executed a redundancy analysis (RDA) (Lepš and Šmilauer, 2003). The significances of the overall RDA ordination as well as the first canonical axis were first calculated using 9999 permutations. As these tests were significant at the $95 \%$ level, we proceeded with forward selection of the explanatory variables to rank the most important ones in this dataset. Explanatory variables that were linearly dependent were excluded from the analysis, but their position in ordination space (the plot) kept as they remain useful to compare to other treatments. All response variables were centred and standardized because of varying measurement units. The same RDA procedure was used to assess the species-specific responses in $\% \mathrm{~N}, \% \mathrm{C}, \delta^{15} \mathrm{~N}, \delta^{13} \mathrm{C}$ and C:N to site water availability or relative root access to groundwater. All these analyses were calculated using CANOCO 5. 


\section{RESULTS}

Comparing foliar $\% \mathrm{~N}, \% \mathrm{C}, \delta^{15} \mathrm{~N}, \delta^{13} \mathrm{C}$ and C: $\mathrm{N}$ revealed significant dissimilarity between the invasive legume A. mearnsii and two co-occurring non-legume native species (PERMANOVA, $\mathrm{t}=13.29, \mathrm{P}<0.001$; data not shown). The analysis showed two significant explanatory axes in this dataset (Fig. 1). Whereas plant functional type, site water availability, and relative root access to groundwater [ $\Psi_{\text {(delta) }}$ ] together explained $70.2 \%$ of the constrained variation in foliar N, C, $\delta^{15} \mathrm{~N}, \delta^{13} \mathrm{C}$ and C:N (RDA, Test on All Axes: Pseudo-F $=$ 34.1, $P<0.001$; data not shown), after forward selection, only plant functional type (Pseudo-F $=45.6, P<0.001)$ and site water availability (Pseudo- $F=34.1, P<0.001$ ) were included in the final ordination (Fig. 1). Together, these two variables explained $68 \%$ of the constrained variation, with site water availability explaining $16 \%$ of the variation, particularly variation in leaf $\delta^{15} \mathrm{~N}$ and $\delta^{13} \mathrm{C}$, and functional type the rest (52\% variation explained). Specifically, \%C, \%N and C:N levels are directly associated with being leguminous, but $\delta^{15} \mathrm{~N}$ and $\delta^{13} \mathrm{C}$ are less species-specific and more related to local moisture conditions.

Testing the effects of the water access on leaf N, C, $\delta^{15} \mathrm{~N}, \delta^{13} \mathrm{C}$ and C: $\mathrm{N}$ within species revealed that, for both A. mearnsii and M. angustifolia, site water availability was most significant in structuring trait variation (variance explained $=56.9 \%$, Pseudo-F 15.8, $P<0.001$; and variance explained $=38.7 \%$, Pseudo-F 8.2, $P<0.001$, respectively; Fig. 2). For $B$. stellatifolium the relative root access to groundwater $\left(\Psi_{\text {(delta) }}\right)$ was the strongest predictor of changes in leaf $\mathrm{N}, \mathrm{C}, \delta^{15} \mathrm{~N}, \delta^{13} \mathrm{C}$ and C:N (variance explained $=23.7 \%$, Pseudo $-F 4.0, P=0.007$; Fig. 2). For all species, total foliar $\% \mathrm{~N}$, and fractionation resulting in ${ }^{15} \mathrm{~N}$ enrichment, was significantly associated with experiencing less water stress.

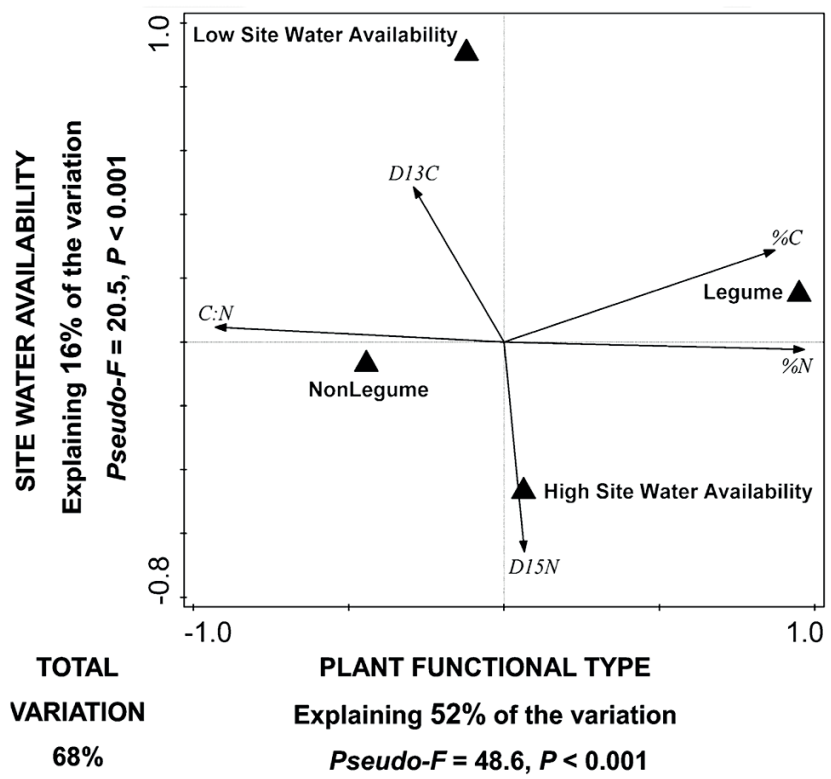

Figure 1

Redundancy analysis (RDA) showing the strength of association and variation explained by plant functional type (legume/non-legume) and site water availability on foliar $N, C, \delta^{15} \mathrm{~N}, \delta^{13} \mathrm{C}$ and $\mathrm{C}: \mathrm{N}$.

\section{DISCUSSION}

Compared with two co-occurring native non-legumes, the invasive legume $A$. mearnsii functioned differently in fynbos riparian zones. Acacia mearnsii had higher leaf $\% \mathrm{~N}$ than the non-leguminous natives as well as higher leaf $\% \mathrm{C}$ and a lower C: $\mathrm{N}$ ratio. In contrast, $\delta^{15} \mathrm{~N}$ levels for all species
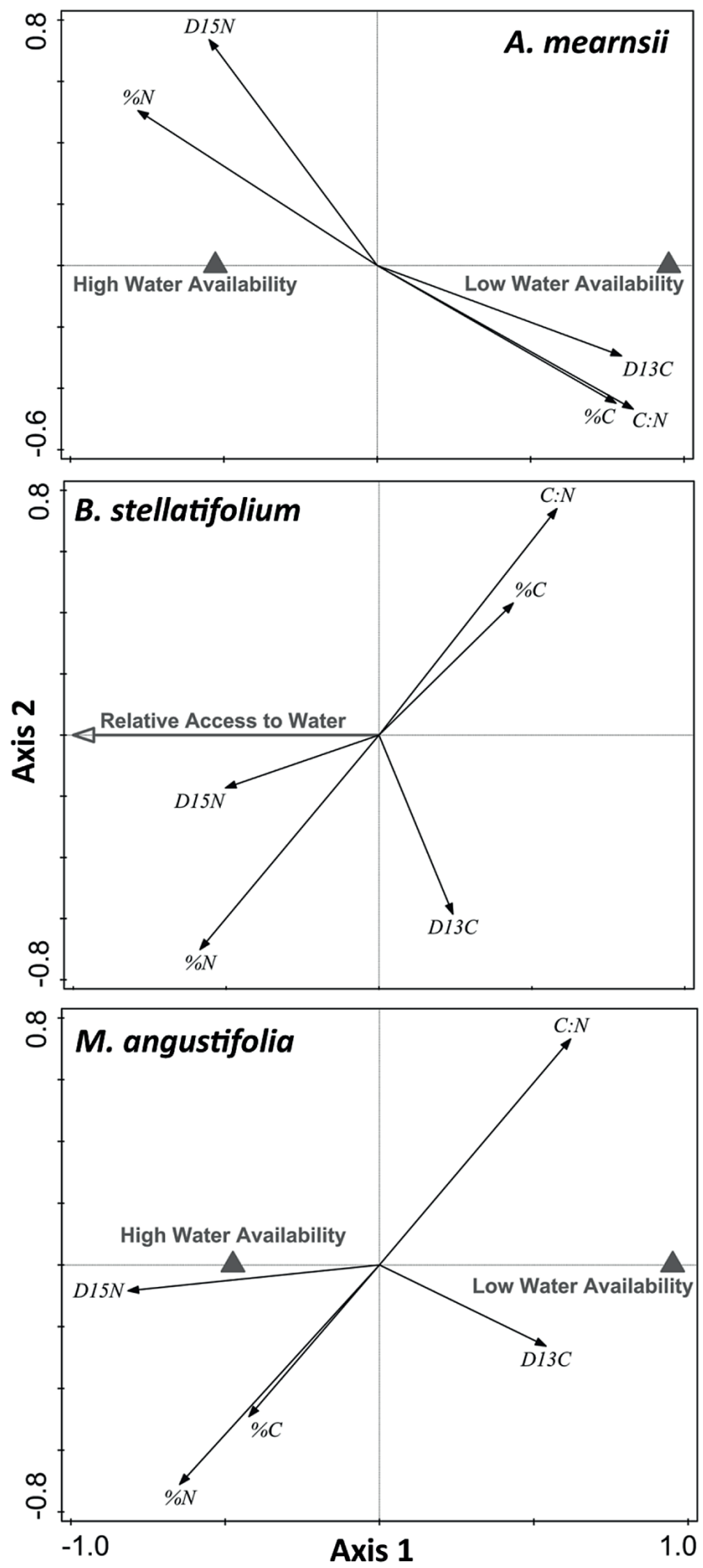

Figure 2

Species-specific redundancy analyses (RDAs) in order to find the strongest explanatory variable(s) (site water availability and relative root access to water $\left[\Psi_{\text {, }}\right]$ ) shaping the distribution in foliar $\% \mathrm{~N}, \% \mathrm{C}$ $\delta^{15} \mathrm{~N}, \delta^{13} \mathrm{C}$ and $\mathrm{C}: \mathrm{N}$ within each species. 
grouped orthogonal to plant functional type, as did $\delta^{13} \mathrm{C}$. This suggests that water availability was influencing foliar ${ }^{15} \mathrm{~N}$ abundance independently from the ability of $A$. mearnsii to fix atmospheric N. The importance of local water availability on plant $\mathrm{N}$ dynamics for the invasive legume was further highlighted as water stress decreased the amount of $\mathrm{N}$ in the leaf tissue. Consistent with Funk et al. (2017), in-situ water availability, as opposed to broad-scale water availability, would aid predictions on the functioning and ecosystem impact of $\mathrm{N}$-enriched A. mearnsii in fynbos riparian ecosystems.

There was a positive relationship between foliar $\delta^{15} \mathrm{~N}$ within these riparian zones and in-situ water availability. For all species examined here, higher water availability in the riparian zone was associated with ${ }^{15} \mathrm{~N}$ enrichment. At the regional scale, mean annual precipitation as an indicator of water availability negatively correlated with $\delta^{15} \mathrm{~N}$ when comparing southern African $\mathrm{C}_{3}$ species (Swap et al., 2004). However, when plants were compared among sites with similar precipitation patterns but different site hydraulic characteristics, for example, landscape topography and moist patches, then local-scale water availability was positively correlated with $\delta^{15} \mathrm{~N}$ (Handley et al., 1999; Ruiz-Navarro et al., 2016). Leaf $\delta^{15} \mathrm{~N}$ in the examined riparian ecosystems appears less related to being leguminous than foliar $\% \mathrm{~N}, \% \mathrm{C}$ and $\mathrm{C}: \mathrm{N}$. We conclude that the patterns in $\mathrm{N}$ isotope enrichment described here were likely associated with local-scale geomorphological and other catchment-specific hydraulic characteristics (Handley et al., 1999; Averill and Finzi, 2011), as was also evident for $\delta^{13} \mathrm{C}$ in these riparian zones (Crous et al., 2012).

Species-specific symbioses with microbes also contribute to variation in foliar $\delta^{15} \mathrm{~N}$ (Högberg, 1997; Boddey et al., 2000; Robinson, 2001; Craine et al., 2009). However, the role of $\mathrm{N}$ fixation by mycorrhizal fungi or bacterial symbionts in altering the $\mathrm{N}$ source available to $A$. mearnsii is unclear from our data. The three co-occurring species varied considerably in $\delta^{15} \mathrm{~N}$ along the same axis making it difficult to infer the specific level of $\mathrm{N}$ fixed by the legume from the atmosphere (Högberg, 1997; Boddey et al., 2000). Instead, the site-moisture association found in this study suggests that nitrification could have been greater under higher site water availability, leaching ${ }^{15} \mathrm{~N}$-depleted $\mathrm{NO}_{3}{ }^{-}$from the soil, and leaving more ${ }^{15} \mathrm{~N}$ enriched $\mathrm{NH}_{4}^{+}$(Högberg, 1997). Still, the microbes suitable for forming nodules are present for $A$. mearnsii species in South Africa (Joubert, 2003; see also Stock et al., 1995). The contribution of symbiotic $\mathrm{N}$-fixation to leaf $\delta^{15} \mathrm{~N}$ variation needs further investigation in relation to a local water availability gradient.

\section{Implications for fynbos riparian zone management}

Persisting populations of $A$. mearnsii in fynbos riparian ecosystems could severely affect $\mathrm{N}$ cycling in the long run, accentuating the effects of non-native legume introductions into historically N-poor soils (Musil and Midgley, 1990; Lee et al., 2017). For example, all the sampled $A$. mearnsii leaves had lower $\mathrm{C}: \mathrm{N}$ ratios than the sampled native species. Since A. mearnsii forms dense stands and replaces mostly non-leguminous native trees in fynbos riparian zones, the quality of leaf litter inputs to streams will change dramatically with invasion, an impact now widely anticipated (Witkowski, 1991; Stock et al., 1995; Forrester et al., 2007; Chamier et al., 2012; Dudley et al., 2014; Lee et al., 2017). Considering water run-off in especially steep, mountainous catchments (such as our studied catchments), this extra $\mathrm{N}$ contributed by invasive plants could be detrimental for water quality due to eutrophication (Vitousek et al., 1997; Drake, 2011; Chamier et al., 2012; Tye and Drake, 2012). In addition, many fynbos riparian areas are already flowing through agricultural regions, a feature often associated with increased nitrogen deposition into the environment (Carpenter et al., 1998; Drake, 2011). Ongoing sewage dumping into rivers is also likely to further exacerbate this situation.

The primary way South Africa addresses A. mearnsii invasion is through clearing, but this is often time consuming, expensive, and only done in a fraction of the total invaded area. Because trait expression of the invasive legume varied according to site water availability, indicating that in-situ functioning and impacts of $A$. mearnsii vary across riparian zones, we can potentially use these data to help prioritize the clearing of wetter sites, particularly if nutrient deposition is the main concern (Emmett et al., 1998). This would complement national clearing initiatives already in place such as South Africa's 'Working for Water' programme (Van Wilgen et al., 1998), where funding is limited (Van Wilgen et al., 2012).

\section{ACKNOWLEDGEMENTS}

We thank the Working for Water programme and the Centre for Invasion Biology at Stellenbosch University for funding, Cape Nature for a research permit (no. AAA008-00022-0028), and all private landowners for access to their properties. RBP was supported by NSF funding (HRD-1547784 and IOS-0845125). ALJ was supported by NSF funding (HRD-1547784 and IOS1252232) and KJE by NRF funding (103841). Two anonymous reviewers greatly improved earlier drafts of this manuscript.

\section{REFERENCES}

ANDERSON MJ (2001) A new method for non-parametric multivariate analysis of variance. Austral Ecol. 26 32-46. https:// doi.org/10.1111/j.1442-9993.2001.01070.pp.x

AVERILL C and FINZI A (2011) Increasing plant use of organic nitrogen with elevation is reflected in nitrogen uptake rates and ecosystem $\delta^{15} \mathrm{~N}$. Ecology 92 883-891. https://doi. org/10.1890/10-0746.1

BODDEY RM, PEOPLES MB, PALMER B and DART PJ (2000) Use of the ${ }^{15} \mathrm{~N}$ natural abundance technique to quantify biological nitrogen fixation by woody perennials. Nutr. Cycl. Agroecosyst. 57 235-270. https://doi.org/10.1023/A:1009890514844

CARPENTER SR, CARACO NF, CORRELL DL, HOWARTH RW, SHARPLEY AN and SMITH VH (1998) Nonpoint pollution of surface waters with phosphorus and nitrogen. Ecol. Appl. 8559 568. https://doi.org/10.1890/1051-0761

CERNUSAK LA, WINTER K and TURNER BL (2009) Plant $\delta^{15} \mathrm{~N}$ correlates with the transpiration efficiency of nitrogen acquisition in tropical trees. Plant Physiol. 151 1667-1676. https://doi. org/10.1104/pp.109.145870

CHAMIER J, SCHACHTSCHNEIDER K, LE MAITRE DC, ASHTON PJ and VAN WILGEN BW (2012) Impacts of invasive alien plants on water quality, with particular emphasis on South Africa. Water SA 38 345-356. https://doi.org/10.4314/wsa.v38i2.19

CRAINE JM, ELMORE AJ, AIDAR MP, BUSTAMANTE M, DAWSON TE, HOBBIE EA, KAHMEN A, MACK MC, MCLAUCHLAN KK, MICHELSEN A, and co-authors (2009) Global patterns of foliar nitrogen isotopes and their relationships with climate, mycorrhizal fungi, foliar nutrient concentrations, and nitrogen availability. New Phytol. 183 980-992. https://doi. org/10.1111/j.1469-8137.2009.02917.x

CROUS CJ, JACOBS SM and ESLER KJ (2012) Drought-tolerance of an invasive alien tree, Acacia mearnsii and two native competitors in fynbos riparian ecotones. Biol. Invasions 14 619-631. https://doi. org/10.1007/s10530-011-0103-y

DRAKE DC (2011) Invasive legumes fix $\mathrm{N}_{2}$ at high rates in riparian areas of an N-saturated, agricultural catchment. J. Ecol. $99515-$ 523. https://doi.org/10.1111/j.1365-2745.2010.01787.x

DUDLEY BD, HUGHES RF and OSTERTAG R (2014) Groundwater 
availability mediates the ecosystem effects of an invasion of Prosopis pallida. Ecol. Appl. 24 1954-1971. https://doi. org/10.1890/13-1262.1

DYE P and JARMAIN C (2004) Water use by black wattle (Acacia mearnsii): implications for the link between removal of invading trees and catchment streamflow response. S. Afr. J. Sci. 100 40-44.

EMMETT BA, BOXMAN D, BREDEMEIER M, GUNDERSEN P, KJØNAAS OJ, MOLDAN F, SCHLEPPI P, TIETEMA A and WRIGHT RF (1998) Predicting the effects of atmospheric nitrogen deposition in conifer stands: evidence from the NITREX ecosystem-scale experiments. Ecosystems 1 352-360. https://doi. org/10.1007/s100219900029

ENRIGHT WD (2000) The effect of terrestrial invasive alien plants on water scarcity in South Africa. Phys. Chem. Earth B 25 237-242. https://doi.org/10.1016/S1464-1909(00)00010-1

FIELD C, MERINO J and MOONEY HA (1983) Compromises between water-use efficiency and nitrogen-use efficiency in five species of California evergreens. Oecologia $60384-389$. https://doi. org/10.1007/BF00376856

FORRESTER DI, SCHORTEMEYER M, STOCK WD, BAUHUS J, KHANNA PK and COWIE AL (2007) Assessing nitrogen fixation in mixed-and single-species plantations of Eucalyptus globulus and Acacia mearnsii. Tree Physiol. 27 1319-1328. https://doi. org/10.1093/treephys/27.9.1319

FUNK JL, NGUYEN MA, STANDISH RJ, STOCK WD and VALLADARES F (2017) Global resource acquisition patterns of invasive and native plant species do not hold at the regional scale in Mediterranean type ecosystems. Biol. Invasions 19 1143-1151. https://doi.org/10.1007/s10530-016-1297-9

GALATOWITSCH S and RICHARDSON DM (2005) Riparian scrub recovery after clearing of invasive alien trees in headwater streams of the Western Cape, South Africa. Biol. Conserv. 122 509-521. https://doi.org/10.1016/j.biocon.2004.09.008

HANDLEY LL, AUSTIN AT, STEWART GR, ROBINSON D, SCRIMGEOUR CM, RAVEN JA and SCHMIDT S (1999) The ${ }^{15} \mathrm{~N}$ natural abundance $\left(\delta^{15} \mathrm{~N}\right)$ of ecosystem samples reflects measures of water availability. Funct. Plant Biol. 26 185-199. https://doi. org/10.1071/PP98146

HÖGBERG P (1997) Tansley Review No. 95: ${ }^{15} \mathrm{~N}$ natural abundance in soil-plant systems. New Phytol. 137 179-203. https://doi. org/10.1046/j.1469-8137.1997.00808.x

JOUBERT C (2003) Rhizobia associated with Australian Acacia species (Acacia mearnsii, Acacia dealbata and Acacia decurrens) in South Africa as determined by sodium dodecyl-sulphate polyacrylamide gel electrophoresis. MSc thesis, University of Pretoria, Pretoria, South Africa.

LEE MR, BERNHARDT ES, BODEGOM PM, CORNELISSEN JHC, KATTGE J, LAUGHLIN DC, NIINEMETS Ü, PEÑUELAS J, REICH PB, YGUEL B, and co-authors (2017) Invasive species' leaf traits and dissimilarity from natives shape their impact on nitrogen cycling: a meta-analysis. New Phytol. 213 128-139. https://doi. org/10.1111/nph.14115

LE MAITRE DC, FORSYTH GG, DZIKITI S and GUSH MB (2016) Estimates of the impacts of invasive alien plants on water flows in South Africa. Water SA 42 659-672. https://doi.org/10.4314/wsa.v42i4.17

LE MAITRE DC, GAERTNER M, MARCHANTE E, ENS E-J, HOLMES PM, PAUCHARD A, O'FARREL PJ, ROGERS AM, BLANCHARD R, BLIGNAUT J and co-authors (2011) Impacts of invasive Australian acacias: implications for management and restoration. Diversity Distrib. 17 1015-1029. https://doi. org/10.1111/j.1472-4642.2011.00816.x

LEPŠ J and ŠMILAUER P (2003) Multivariate analysis of ecological data using CANOCO. Cambridge University Press, UK.

MUSIL CF and MIDGLEY GF (1990) The relative impact of invasive Australian acacias, fire and season on the soil chemical status of a sand plain lowland fynbos community. S. Afr. J. Bot. 56 419-427. https://doi.org/10.1016/S0254-6299(16)31036-5

NEW M (2002) Climate change and water resources in the southwestern Cape, South Africa. S. Afr. J. Sci. 98 1-8.

NIELSEN JA, FREW RD, WHIGHAM PA, CALLAWAY RM and DICKINSON KJM (2016) Thyme travels: $15 \mathrm{~N}$ isoscapes of Thymus vulgaris L. invasion in lightly grazed pastoral communities. Austral Ecol. 41 28-39. https://doi.org/10.1111/aec.12284
PETCHY OL and GASTON KJ (2002) Functional diversity (FD), species richness and community composition. Ecol. Lett. $5402-$ 411. https://doi.org/10.1046/j.1461-0248.2002.00339.x

ROBINSON D (2001) $\delta^{15} \mathrm{~N}$ as an integrator of the nitrogen cycle. Trends Ecol. Evol. 16 153-162. https://doi.org/10.1016/ S0169-5347(00)02098-X

RUIZ-NAVARRO A, BARBERÁ GG, ALBALADEJO J and QUEREJETA JI (2016) Plant $\delta^{15} \mathrm{~N}$ reflects the high landscape-scale heterogeneity of soil fertility and vegetation productivity in a Mediterranean semiarid ecosystem. New Phytol. 212 1030-1043. https://doi.org/10.1111/nph.14091

SARDANS J, BARTRONS M, MARGALEF O, GARGALLOGARRIGA A, JANSSENS IA, CIAIS P, OBERSTEINER M, SIGURDSSON BD, CHEN HY and PENUELAS J (2017) Plant invasion is associated with higher plant-soil nutrient concentrations in nutrient poor-environments. Glob. Change Biol. 23 1282-1291. https://doi.org/10.1111/gcb.13384

SCHULZE ED, GEBAUER G, ZIEGLER H and LANGE OL (1991) Estimates of nitrogen fixation by trees on an aridity gradient in Namibia. Oecologia 88 451-455. https://doi.org/10.1007/BF00317592

STEYNOR AC, HEWITSON BC and TADROSS MA (2009) Projected future runoff of the Breede River under climate change. Water $S A$ $35433-440$.

STOCK WD, WIENAND KT, BAKER AC (1995) Impacts of invading $\mathrm{N}_{2}$-fixing Acacia species on patterns of nutrient cycling in two Cape ecosystems: evidence from soil incubation studies and ${ }^{15} \mathrm{~N}$ natural abundance values. Oecologia 101 375-382. https://doi.org/10.1007/ BF00328825

SWAP RJ, ARANIBAR JN, DOWTY PR, GILHOOLY WP and MACKO SA (2004) Natural abundance of ${ }^{13} \mathrm{C}$ and ${ }^{15} \mathrm{~N}$ in $\mathrm{C} 3$ and $\mathrm{C} 4$ vegetation of southern Africa: patterns and implications. Glob. Change Biol. $10350-358$. https://doi. org/10.1111/j.1365-2486.2003.00702.x

TYE DRC and DRAKE DC (2012) An exotic Australian Acacia fixes more $\mathrm{N}$ than a coexisting indigenous Acacia in a South African riparian zone. Plant Ecol. 213 251-257. https://doi.org/10.1007/ s11258-011-9971-6

VAN WILGEN BW, FORSYTH GG, LE MAITRE DC, WANNENBURGH A, KOTZÉ JD, VAN DEN BERG E and HENDERSON L (2012) An assessment of the effectiveness of a large, national-scale invasive alien plant control strategy in South Africa. Biol. Conserv. 148 28-38. https://doi.org/10.1016/j. biocon.2011.12.035

VAN WILGEN BW, LE MAITRE DC and COWLING RM (1998) Ecosystem services, efficiency, sustainability and equity: South Africa's Working for Water programme. Trends Ecol. Evol. 13378. https://doi.org/10.1016/S0169-5347(98)01434-7

VAN WILGEN BW, NEL JL and ROUGET M (2007) Invasive alien plants and South African rivers: a proposed approach to the prioritization of control operations. Freshwater Biol. 52 711-723. https://doi.org/10.1111/j.1365-2427.2006.01711.x

VITOUSEK PM, MOONEY HA, LUBCHENCO J and MELILLO JM (1997) Human domination of Earth's ecosystems. Science 277494 499. https://doi.org/10.1126/science.277.5325.494

WALKER B, KINZIG A and LANGRIDGE J (1999) Plant attribute diversity, resilience, and ecosystem function: The nature and significance of dominant and minor species. Ecosystems 2 95-113. https://doi.org/10.1007/s100219900062

WILSON JR, GAERTNER M, GRIFFITHS CL, KOTZÉ I, LE MAITRE DC, MARR SM, PICKER MD, SPEAR D, STANFORD L, RICAHRDSON DM, and co-authors (2014) Biological invasions in the Cape Floristic Region: history, current patterns, impacts, and management challenges. In: Allsopp N, Colville JF, Verboom GA (eds.) Fynbos: Ecology, Evolution, and Conservation of a Megadiverse Region. Oxford University Press, United Kingdom.

WITKOWSKI ETF (1991) Effects of invasive alien acacias on nutrient cycling in the coastal lowlands of the Cape fynbos. J. Appl. Ecol. 28 1-15. https://doi.org/10.2307/2404109

WRIGHT IJ, REICH PB, WESTOBY M, ACKERLY DA, BARUCH Z, BONGERS F, CAVENDER-BARES J, CHAPIN T, CORNELISSEN HC, DIEMER M, and co-authors (2004) The worldwide leaf economics spectrum. Nature 428 821-827. https://doi.org/10.1038/ nature 02403 


\begin{tabular}{|c|c|c|c|c|c|c|}
\hline \multicolumn{7}{|c|}{$\begin{array}{l}\text { TABLE A1 } \\
\begin{array}{l}\text { Raw foliar } \mathrm{N}, \mathrm{C}, \delta^{15} \mathrm{~N}, \delta^{13} \mathrm{C} \text { and } \mathrm{C}: \mathrm{N} \text { data measured for the invasive legume Acacia mearnsii, and two native co-occurring non- } \\
\text { legumes Brabejum stellatifolium and Metrosideros angustifolia in three fynbos riparian zones, South Africa. }\end{array}\end{array}$} \\
\hline Species & Individual & $\mathrm{D} 15 \mathrm{~N}$ & Foliar \%C & Foliar \%N & $\mathrm{C}: \mathrm{N}$ & $\mathrm{D} 13 \mathrm{C}$ \\
\hline \multicolumn{7}{|l|}{ JONKERSHOEK } \\
\hline B. stellatifolium & 1 & 0.60 & 49.19 & 0.94 & 52.31 & -26.04 \\
\hline B. stellatifolium & 2 & 0.42 & 49.43 & 0.98 & 50.30 & -26.79 \\
\hline B. stellatifolium & 3 & 1.55 & 48.82 & 0.94 & 51.84 & -24.17 \\
\hline B. stellatifolium & 4 & 1.43 & 49.38 & 1.21 & 40.78 & -25.38 \\
\hline B. stellatifolium & 5 & 1.41 & 47.52 & 1.15 & 41.14 & -24.12 \\
\hline Mean & & 1.08 & 48.87 & 1.05 & 47.27 & -25.30 \\
\hline M. angustifolia & 1 & 1.10 & 48.68 & 1.22 & 39.99 & -23.31 \\
\hline M. angustifolia & 2 & 0.39 & 48.78 & 0.91 & 53.72 & -23.67 \\
\hline M. angustifolia & 3 & -1.86 & 48.96 & 1.38 & 35.47 & -25.04 \\
\hline M. angustifolia & 4 & -1.17 & 49.15 & 1.30 & 37.94 & -23.13 \\
\hline M. angustifolia & 5 & 1.86 & 48.76 & 1.24 & 39.42 & -22.64 \\
\hline Mean & & 0.06 & 48.87 & 1.21 & 41.31 & -23.56 \\
\hline A. mearnsii & 1 & -2.30 & 54.26 & 2.82 & 19.27 & -25.93 \\
\hline A. mearnsii & 2 & -2.13 & 53.24 & 3.06 & 17.40 & -25.71 \\
\hline A. mearnsii & 3 & -2.11 & 52.26 & 2.97 & 17.59 & -25.39 \\
\hline A. mearnsii & 4 & -1.83 & 52.01 & 3.44 & 15.13 & -24.72 \\
\hline Mean & & -2.09 & 52.94 & 3.07 & 17.35 & -25.44 \\
\hline \multicolumn{7}{|l|}{ BAINSKLOOF } \\
\hline B. stellatifolium & 1 & -4.92 & 49.83 & 0.92 & 53.96 & -25.22 \\
\hline B. stellatifolium & 2 & -2.71 & 49.17 & 0.96 & 51.26 & -24.45 \\
\hline B. stellatifolium & 3 & -3.31 & 49.70 & 0.95 & 52.20 & -24.71 \\
\hline B. stellatifolium & 4 & -2.42 & 48.61 & 1.02 & 47.63 & -24.30 \\
\hline B. stellatifolium & 5 & -2.10 & 48.43 & 1.02 & 47.66 & -25.21 \\
\hline Mean & & -3.09 & 49.15 & 0.97 & 50.54 & -24.78 \\
\hline M. angustifolia & 1 & -4.66 & 49.62 & 0.99 & 50.26 & -21.14 \\
\hline M. angustifolia & 2 & -6.52 & 48.13 & 0.92 & 52.25 & -21.85 \\
\hline M. angustifolia & 3 & -3.10 & 48.33 & 1.00 & 48.41 & -22.37 \\
\hline M. angustifolia & 4 & -3.23 & 48.70 & 0.96 & 50.96 & -23.94 \\
\hline M. angustifolia & 5 & -5.14 & 48.49 & 0.83 & 58.26 & -24.19 \\
\hline Mean & & -4.53 & 48.65 & 0.94 & 52.03 & -22.70 \\
\hline A. mearnsii & 1 & -1.17 & 55.38 & 2.67 & 20.74 & -24.22 \\
\hline A. mearnsii & 2 & -3.06 & 55.52 & 2.10 & 26.38 & -24.32 \\
\hline A. mearnsii & 3 & -1.91 & 54.61 & 2.62 & 20.87 & -22.70 \\
\hline A. mearnsii & 4 & -3.23 & 54.46 & 2.25 & 24.24 & -23.38 \\
\hline A. mearnsii & 5 & -2.57 & 53.72 & 2.34 & 22.99 & -24.31 \\
\hline Mean & & -2.39 & 54.74 & 2.39 & 23.04 & -23.79 \\
\hline
\end{tabular}


TABLE A1 (cont.)

Raw foliar $\mathrm{N}, \mathrm{C}, \delta^{15} \mathrm{~N}, \delta^{13} \mathrm{C}$ and C:N data measured for the invasive legume Acacia mearnsii, and two native co-occurring nonlegumes Brabejum stellatifolium and Metrosideros angustifolia in three fynbos riparian zones, South Africa.

\begin{tabular}{|c|c|c|c|c|c|c|}
\hline Species & Individual & D15N & Foliar $\% C$ & Foliar $\% \mathrm{~N}$ & $\mathrm{C}: \mathrm{N}$ & D13C \\
\hline \multicolumn{7}{|l|}{ DUTOITSKLOOF } \\
\hline B. stellatifolium & 1 & -2.07 & 49.30 & 0.98 & 50.37 & -27.73 \\
\hline B. stellatifolium & 2 & -1.96 & 47.69 & 0.88 & 54.43 & -27.45 \\
\hline B. stellatifolium & 3 & -2.17 & 48.72 & 1.13 & 43.15 & -25.45 \\
\hline B. stellatifolium & 4 & -2.36 & 48.14 & 1.22 & 39.58 & -27.48 \\
\hline B. stellatifolium & 5 & -1.82 & 49.86 & 0.81 & 61.54 & -26.04 \\
\hline Mean & & -2.08 & 48.74 & 1.00 & 49.81 & -26.83 \\
\hline M. angustifolia & 1 & -2.64 & 49.81 & 1.18 & 42.131 & -25.60 \\
\hline M. angustifolia & 2 & -1.99 & 48.79 & 0.87 & 56.256 & -25.23 \\
\hline M. angustifolia & 3 & -0.11 & 49.27 & 1.15 & 42.753 & -23.82 \\
\hline M. angustifolia & 4 & -0.28 & 50.07 & 1.29 & 38.844 & -23.88 \\
\hline M. angustifolia & 5 & -0.95 & 48.95 & 1.29 & 38.086 & -26.24 \\
\hline Mean & & -1.19 & 49.38 & 1.16 & 43.614 & -24.95 \\
\hline A. mearnsii & 1 & -0.57 & 50.59 & 3.71 & 13.637 & -27.88 \\
\hline A. mearnsii & 2 & -1.43 & 52.71 & 2.81 & 18.77 & -26.15 \\
\hline A. mearnsii & 3 & -0.46 & 51.76 & 3.02 & 17.111 & -27.05 \\
\hline A. mearnsii & 4 & -1.24 & 53.13 & 2.92 & 18.164 & -26.11 \\
\hline A. mearnsii & 5 & -0.82 & 52.21 & 2.94 & 17.78 & -28.03 \\
\hline Mean & & -0.90 & 52.08 & 3.08 & 17.092 & -27.05 \\
\hline
\end{tabular}

